\title{
Science in South Africa.
}

THE twenty-second annual meeting of the South African Association for the Advancement of Science was held at Cape Town on July $7-12$, under the presidency of Prof. J. A. Wilkinson, professor of chemistry in the University of the Witwatersrand, Johannesburg. The meeting was well attended, and more than 80 papers were read. Joint meetings of sections were held for a symposium on veld-burning and for the paper by Prof. H. B. Fantham on "Heredity in Man: its importance both biologically and educationally." There were various visits to places of scientific and historic interest in the neighbourhood, and a popnlar lecture was delivered by H.M. Astronomer at the Cape, Mr. H. Spencer Jones, on "Wireless Messages from the Stars." A scientific conversazione was arranged by the Royal Society of South Africa, and there was a reception by the Consul-General for Belgium.

The president of the Association, Prof. J. A. Wilkinson, gave as his presidential address, "A Review of some Developments in Chemistry during this Century." Commencing with a historical résumé, a synopsis was then given of progress in knowledge of the zero valency elements, radium developments, cathode rays, positive rays, atomic structure, X-ray spectra, newer work on isotopes, the configuration of the atom, X-ray crystal analysis, colloid chemistry and its developments, Werner's co-ordination theory, hydrogen-ion concentrations, and the theory of solutions. Progress in organic and inorganic analysis was noted, and the methods of soil analysis were outlined. The address concluded with a statement of the needs of research and an appeal for such research.

The presidential address to Section $\mathrm{A}$ was delivered by Dr. J. K. E. Halm, on "The Luminosities of the Stars." The history of progress in the several branches of astronomy was traced. The visual and photographic methods of obtaining photometrically correct magnitudes were discussed, and the practical applications of Planck's formula to the distribution of energy in stellar spectra were outlined. Methods of determining distances of stars were noted, and some new results recently obtained at the Cape Observatory in connexion with masses of the stars were outlined. The need of adequate equipment of observatories was urged.

Dr. A. L. du Toit, president of Section B, took as his subject, "The Contribution of South Africa to the Principles of Geology," in which he described the advances made, indicated the bearing of such discoveries in advancing geological theory, and suggested lines for future research. In mineralogy, reference was made to crocodilite and African "jade." The different origins of several kinds of asbestos in the Union, stanniferous ores in the Bushveld tin fields, gold-bearing conglomerates and kimberlite were discussed, and the Bushveld igneous complex of the Transvaal indicated as a field for research. The history of past glaciations in South Africa, and evidence of at least four past glaciations, were presented. The evidence for the existence of Gondwanaland and the hypothesis of continental disruption were discussed. The palxontological vertebrate assemblage of South Africa and jts development were noted, as was the well-known Glossopteris flora. The address concluded with an appeal for more attention to field geology.

"Kirstenbosch, South African Botany and Nature Reserves," was the subject of the presidential address to Section C, given by Prof. R. H. Compton, who directed attention to the need for greater output of research, and for developing on national rather than on local lines. The creation of the National Botanic Gardens at Kirstenbosch, their history, manifold botanical possibilities due to situation, rainfall, variety of soil and many types of vegetation were described. Substations are projected, one of which, the Karroo garden, has materialised. The wide scope of the intended activities of the National Gardens was outlined and the need of pure research, in contrast to applied work, was emphasised. Kirstenbosch is also a sanctuary for the native flora and fauna of South Africa. The importance of the preservation of mountain catchment areas by an adequate covering of natural vegetation, the prevention of unnecessary veld-burning, the protection of the natural flora, and its preservation under natural conditions were urged.

Prof. E. H. Cluver dealt with " Some Applications of Physiology to Industrial Hygiene " in his presidential address to Section D. It was pointed out that all improvements directed towards improving health also increase efficiency. Developments in work on industrial fatigue, tests for the assessment of fatigue, arrangement of work periods, rhythmic movements, work postures, etc., were discussed. The importance of atmospheric conditions, such as heat and moisture, particularly in South Africa, in the mines and in factories, was emphasised. Dusty conditions, particularly silicosis, were considered. Dietetics were discussed from the point of view of under-development, correct feeding, and adequate supply of vitamins. It was pointed out that stunted growth and low resistance to pathogenic organisms are accompanied by industrial discontent, and physical inefficiency by inadequate output.

The presidential address to Section E, "The Education of the Native," was delivered by Mr. W. G. Bennie, who has had thirty years' experience of native education in the Cape Province. The historical landmarks in native education were first outlined, and the nature or scope of native education discussed. In primary schools a fairly liberal course with a strong industrial bias was recommended, the native language being the medium of instruction in early life and one of the official languages later. Instruction in physiology and hygiene and some form of handwork is essential. Secondary school work should resemble that for Europeans, suitable options being provided. Agricultural training is of great importance. A sympathetic attitude towards native education was urged, since the raising of the native is necessary for economic development, for the maintenance of our own civilisation, and from motives of justice.

The Chief Archivist of the Union, Mr. Graham Botha, delivered his presidential address to Section F on "The Public Archives-their Value to Scientific Research." After dealing with the widespread interest of the Archives, archive administration and availability, the Archives as a great storehouse of materials for research was dealt with at some length. The historian can find documents for reconstructing the history of the race and for studies in political and social evolution; the political economist can obtain materials relating to wages, land tenure, currency, commerce, development of resources; agricultural progress can be traced; sociologists can study to advantage the organisation and development of society in all its grades in South Africa. Documents on agrarian practices, plant life and forest reports are not only of intrinsic interest but also of economic importance. The Archives thus can provide abundance of material of great diversity for investigators in numerous fields of knowledge. 
It is only possible to notice briefly some of the interesting papers read before the various sections.

In Section A, Dr. J. D. Schonken gave a paper on desiccation and how to measure it, defining desiccation, exsiccation, and siccation. He considers that a growing irregularity of rainfall provides a more trustworthy index of desiccation than the measurement of rainfall in inches. Dr. J. S. van der Lingen contributed a paper on the planetesimal hypothesis and dealt with uniform belts of planetesimals and equatorial accelerations. Dr. B. F. J. Schonland gave a paper on the scattering of the cathode rays, considering that the law of force in an encounter between an electron and an atomic nucleus appears to be that of the inverse square.

In Section B, Dr. B. de C. Marchand read a paper on the origin of black turf soils in the Transvaal. These are really clays, derivatives of plagioclase, and not particularly rich in organic matter. Mr. C. W. van der Merwe dealt with the formation of soil from diabase in the central Transvaal, the weathering being mainly due to chemical decomposition. Prof. G. H. Stanley reviewed metallurgical progress in the Transvaal during the decade I9I4-I924. Mr. T. Leslie discussed the huge Transvaal formation of dolomite, which is very suitable for fluxes. Dr. J. J. Theron and Mr. J. V. Cutler gave a paper on the function of nicotine in tobacco, which their investigations show to be a storage product and not waste. Mr. Cutler also gave an account of the growth, ash content and constituents, and nicotine content of tobacco grown on experimental fertiliser plots at the Rustenburg Cotton and Tobacco Station. Mr. Steenkamp described the chemical composition of the latex of a Euphorbia. Dr. Theron wrote on the reaction of some Transvaal soils. Messrs. A. J. Pelling and J. B. Robertson further discussed the reciprocal saltpair formed by sodium chloride and calcium nitrate. Studies on the thiazoles were contributed by Dr. J. L. B. Smith with Messrs. E. H. Flack and A. R. Inggs. Mr. O. G. Backeberg gave a paper on the theory of indicators. Mr. W. Torrance described his studies on metamorphic mudstones, and Dr. F. Nopcsa made a palæontological contribution on the systematic position of Saurosternon and Tangasaurus.

In Section C, Dr. R. Marloth gave a paper on the determination of acidity of soils. $\mathrm{He}$ considers Truog's test convenient and sufficiently accurate for the farmer. Prof. C. IE. Bremekamp made a contribution on hydrotropism and thigmotropism of roots, and Prof. R. S. Adamson described some new cases of secondary growth in monocotyledons. The seaweeds of the Cape Peninsula and their distribution were discussed by Mrs. M. R. Levyns, the Atlantic and Indian Ocean seaweeds being contrasted. Notes on the aquatic flora of South Africa were presented by Miss E. Stephens. Mr. A. Stead contributed a paper on Saaidam terraces in the Karroo, a method valuable for securing an underground water-supply. Dr. J.S. van der Lingen gave three papers on plant pigments, including those of Bacillus pyocyaneus, which he has examined spectroscopically. Dr. W. F. Barker summarised his results on the function of the chloroplasts in carbon dioxide assimilation. Dr. T. Sim gave further notes on mosses from the south-west part of South Africa, and Prof. P. A. van der Bijl continued his descriptions of South African Polyporeæ. Mr. Pont contributed a paper on osmotic pressure in correlation with growth form and habitat. Mr. J. Phillips gave an interesting paper on the biology, ecology, and sylviculture of a valuable indigenous timber tree, Ocotea bullata, known as " stinkwood."

The symposium on veld-burning was opened by Dr. R. Marloth, who dealt in general with the problem, illustrating from occurrences in the South-west Cape, where thick evergreen scrub has been replaced by fireresisting bulbs as a result of veld-burning, the run-off being greatly increased. Capture of water from the south-east cloud by mountain vegetation was urged. Mrs. M. R. Levyns spoke of the effect of veld fires on two contrasted areas in the Cape Peninsula. Mr. Pillans described the destruction of indigenous vegetation in the Cape and condemned veld-burning. Mr. Graham Botha contributed an historical account of the practice, originally derived from the Hottentots.

In Section D, Mr. A. D. Stammers dealt with the effect of altitude on health and longevity; from physiological experiments and statistical data he concludes that if certain minor precautions are observed, detrimental effects will not accrue from long residence at altitudes of 4000 to 6000 feet. Dr. Ânnie Porter gave an account of five kinds of insect larva observed by her in man in South Africa. Prof. R. W. M. Mettam described an ox liver possessing accessory lobes and so being more equine than bovine in character, and also described the greatly enlarged condition of the petrous temporal bone of a calf. Prof. H. B. Fantham gave an account of his further researches on parasitic Protozoa, and described inter alia a new Entamoba from a duck, a new Herpetomonas from the larva of Eristalis, and several new Trichodinas. Prof. Fantham aiso summarised the observations on various protozoal and helminthic parasites from South African Amphibia that have been investigated by Miss C. Weinbrenn and himself, and presented a further report, in collaboration with Miss N. F. Paterson, of their researches on the protozoal fauna of certain South African soils. The distribution of the soil Protozoa differs in the coastal belt, the Karroo belt, and the High Veld. It also varies in soils from False and Table Bays, which are adjacent. More work on seasonal variation in soil Protozoa and a preliminary account of the effect on them of veld-burning were also recorded. Mr. H. H. Curson presented a paper on the causal agents of nagana, showing that Trypanosoma brucei, $T$. vivax, and $T$. congolense are all associated with this condition in Zululand. Mr. H. H. Curson and Mr. J. M. Hugo discussed the preservation of game in South Africa, giving details of the various game reserves and measures for game preservation. Dr. C. S. Grobbelaar gave an account of his interpretation of the blood vascular system of Xenopus lavis. Dr. M. M. Prates sent a note on the fusiform bacillus-spirochæte association found among natives in Portuguese East Africa. Mr. J. Hewitt discussed the irreversibility of evolution, giving examples, particularly among spiders, tending to show that reversible evolution is possible by loss of mutations. Prof. J. E. Duerden and Miss M. Ritchie traced the development of the merino wool fibres from their first appearance to the birth of the lamb. Prof. Duerden and Miss G. Brock described the structure of the lining of the gizzard of the ostrich. A joint meeting was held with Sections $\mathrm{E}$ and $\mathrm{F}$ for a paper by Prof. H. B. Fantham on heredity in man, its importance both biologically and educationally. In this an account was given of various heritable traits, physical, mental, and moral shown in man, both normal and abnormal characteristics being considered. The interaction of eugenics and euthenics was noted. Sociological applications were made, and suggestions put forward for educational betterment.

In Section E, Miss D. Earthy described various body markings employed more particularly by the VaChopi and VaLenge of Portuguese East Africa. Mr. A. J. H. Goodwin dealt with AmaPondo sibs. Col. W. E. Hardy exhibited stone implements col-

NO. 2874 , vOL. I I 4$]$ 
lected in the Cape and demonstrated methods of preparing them. Mr. G. D. Laing gave an account of Strandlooper skulls from 7itzikama, showing transition from a short face with light zygomatics to a long face with prominent zygomatics. Prof. R. A. Dart gave a paper on the Rooiberg cranium, which is probably not that of an ancient miner, but of a man who used the old mine as a dowelling. Prof. A. Radcliffe Brown gave details of the position of the mother's brother among the Bantu, a proper understanding of which is very necessary in dealing with native peoples. Prof. W. A. Norton and Mr. H. Velaphe presented sixty-eight Sesuto riddles with translations of the same. The science of tonetics and its application to Bantu languages was discussed by Dr. D. M. Beach.

In Section F, Advocate G. T. Morice discussed psycho-analysis and criminals, criticising various methods and certain new books. He considers Freudian psycho-analysis of little use, as it concentrates on the sexual and ignores other instincts. Prof. S. F. Gie gave an account of the economic development of South Africa from I652 to I795. Prof. R. D. Nauta gave a reasoned résumé of the moral value of Molière's works. The conception of intelligence was dealt with by Prof. R. W. Wilcocks.
Much interest attached to a paper by Mr. C. S. Richards on the monetary history of South Africa since union, in which the currency problem and inflation of currency were dealt with, and a return to the gold standard advocated. Of much historic interest also was Miss M. L. Hodgson's paper on the Hottentot question in South Africa down to 1828 . Prof. E. H. Brookes discussed the changes in native economic life in South Africa due to European influence and changes in Europeans due to native influences. He advocates economic differentiation and native development in agriculture and native industries, with no detachment of their natural leaders from the bulk of the Bantu. Mrs. Mabel Palmer gave an account of a South African Whitley Council as shown in the organisation of the printing industry. Rev. R. Balmforth pleaded for a more fully representative international authority than the present League of Nations.

As a result of Dr. Fantham's paper, the Eugenics and Genetics Committee of the Association has renewed its activities.

The next anual meeting of the Association will be held at Oudtshorn, under the presidency of General J. C. Smuts, in July 1925.

\section{H. B. Fantham.}

\section{Sex Determination.}

$\mathrm{M}^{\mathrm{A}}$ NKIND has always been intrigued by the problem of what are the factors that determine sex, but it is only comparatively recently that a real light has been thrown upon this subject. The influence of the sex glands upon certain characteristics of the body has, it is true, been known for many centuries, as witnessed by the effects of castration, but the mechanism by which these changes are produced was obscure. With the discovery by Oliver and Schäfer in I894 of the effects of suprarenal extracts upon blood pressure, a mechanism by which one part of the body may. influence another (other than that involved in the intervention of the nervous system) was suggested, and experiments have shown that the action which the sex glands exert upon the body generally must be due to a substance or substances- "hormones" in fact, or chemical messengers - circulating in the blood stream. Thus removal of the testes or ovaries from their normal position to another part of the body produces no alteration of bodily appearance, although all nervous connexions must necessarily have been severed. Complete extirpation of both glands, however; leads to disappearance of those characters which are correlated with sex and are known as the secondary sex characteristics.

It is interesting to note that these characters vary considerably according to the species: thus the antlers in certain species of deer are present in the male sex only; the combs and spurs of cocks are peculiar to the male; in male frogs in the breeding season a clasping pad is developed on the thumbs. The external differences, however, between the sexes are especially well marked in birds, where the two sexes usually possess a very different plumage. For this reason, perhaps, those rare cases in which the creature during its lifetime changes its sex have been more frequently described in birds: these "freaks" have always excited much curiosity. In a recent paper in Science Progress (October 1924) F. W. Rogers Brambell describes some examples of this transformation. The change is always of a female into a male, and post mortem examination discloses the presence of testicular tissue as well as or without ovarian tissue : at times the latter is mostly degenerated. The change is therefore due to the development of a sex gland of the opposite sex ; but the transforma- tion is usually incomplete, some of the female characteristics remaining unchanged.

Now after simple removal of the sex glands from an animal the characteristics of the opposite sex do not usually develop; the change in appearance is towards a neutral type which, according to the species, may be either nearer to the male as in birds or to the female as in mammals. It is, however, certain that the actual appearance of the opposite sex depends on the development of the appropriate sex gland. Does this imply that every organism in species with separate sexes contains within itself the factors upon which the sexes ultimately depend ? Probably this does not occur normally, the sex of the individual being determined at conception, possibly by the particular arrangement of the chromosomes in the ovum and spermatozoon which unite in fertilisation. The sex-determining chromosomes pass into the sex glands and thus influence the development of the somatic cells along the lines of the particular sex involved. In certain rare cases, however, of hermaphroditism or sex reversal the sex chromosomes of both sexes must be present, and the result is either a mixture of the tivo, or one predominates either completely or for a time.

This view is borne out also by the fact mentioned above that simple removal of the sex glands does not produce the characters of the opposite sex: on the other hand, the somatic cells are capable of being influenced by the secretions of either gland, and after removal of the normal glands, grafting of the glands of the opposite sex from an animal of the same species leads to the development of the characteristics of the grafted sex. The factors which produce any particular arrangement of the chromosomes in the ovum or spermatozoon and so lead to the appearance of the corresponding sex are not yet completely elucidated : it is, however, suggestive that in pigeons and doves, Riddle found a predominance of males amongst the offspring when the parents were the most vigorous, early in the breeding season. One factor which influences the constitution of the spermatozoon or ovum is therefore the general metabolic condition of the parent. Research along these lines may lead in the future to knowledge which will enable mankind so to arrange the conditions as to produce, with a fair amount of certainty, an offspring of the sex desired. 